\title{
Novice Teachers' Satisfaction with Teacher Preparation and Recommendations for Improving Teacher Training
}

\author{
Eveli Laats \\ University of Tartu (Estonia)
}

\begin{abstract}
According to studies, students' progress is influenced by teachers' qualification. Despite their qualification, novice teachers have adjusting difficulties and soon leave the profession, caused by drawbacks in teacher preparation. The qualitative study aimed to identify satisfaction with teacher preparation among teacher training graduates and make recommendations for improving teacher training. It involved 14 teacher-education graduates. The data of the semi-structured interviews were analysed using qualitative content analysis. The results revealed satisfaction with a thorough theoretical basis and acquired skills: reflection, compiling study materials, information search; and dissatisfaction with excessive theoretical focus and insufficiently taught skills: using digital tools, teaching students with special needs, preventing burnout; short and rigid pedagogical practice. Graduates suggested using more active learning methods and teaching skills practically, also inviting novice teachers to share their experience; flexing pedagogical practice.
\end{abstract}

Keywords: novice teachers, teacher training, teacher preparation, recommendations for improving

\section{Introduction}

The fact that novice teachers quit their jobs is a common problem in many countries (Fantilli \& McDougall, 2009). One of the reasons why novice teachers leave the profession shortly after qualifying is the difficulties they encounter during their period of work adaptation (Farrell, 2012). Novice teachers who have left the profession often explain their decision with dissatisfaction with the content and conditions of their work and admit to little or insufficient preparation in a number of competencies relevant to teaching (Aud et al., 2013; Ingersoll, Merrill, \& Stuckey, 2014). However, according to research, the performance of students is most influenced by the competence of the teacher (Cunningham, 2019).

In Estonia, the people who enter teacher training have received lower than average state examination results, and on an international level, the competencies of Estonian teaching alumni are also lower than those in other countries. Thus, there is a growing need for more competent graduates of teacher education (Valk, 2016). However, there are not enough graduates of teacher training in Estonia to cover the current workforce needs or when taking into consideration the ageing teachers (Haridus- ja 


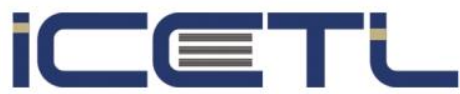

21-23 FEBRUARY, 2020

\section{$3^{\text {rd }}$ International Conference on Research in EDUCATION, TEACHING and LEARNING}

ROME, ITALY

Teadusministeerium, 2018). One third of teacher education students already work as teachers during their studies. Moreover, a large percentage of the graduates of teacher training leave the profession after qualifying (Haridus- ja Teadusministeerium, 2018). One fifth of those who have completed teacher training do not enter the profession at all, about fifty percent work as teachers for less than five years, and one third quits teaching within a year (Selliov \& Vaher, 2018).

To provide better preparation for novice teachers, it is necessary to identify the specific causes of dissatisfaction at starting work as a teacher and, in turn, to develop teacher training based on that information (Feuer, Floden, \& Chudowsky, 2013). As a result, it was decided to conduct a qualitative research among teaching alumni. The aim of the research was to identify satisfaction with teacher preparation among teacher training graduates and make recommendations for improving teacher education.

\section{Theoretical overview}

Novice teachers, whose professional identity has not yet fully developed, face a number of challenges when starting their career (Farrell, 2012). Difficulties occur both when planning planning and guiding the learning processes. Problems include lack of time and classroom management, as well as related documentation. In addition, teachers often encounter difficult communication situations with parents, colleagues, and management. Mental tension, anxiety, and stress at work have also been described as hardships (Fantilli \& McDougall, 2009).

Despite the little experience of novice teachers, expectations of their competence are the same as their more experienced colleagues since the first day. This attitude is also perceived by the teachers themselves, who often have to deal with problems without sufficient support from the school or completely independently (Farrell, 2012). This situation, in turn, creates insecurity in the performance of their duties, doubts about the suitability of teaching profession, and deepens stress. About one half of novice teachers have considered leaving the teaching profession because of the arisen problems (Fantilli $\&$ McDougall, 2009). Moreover, the lack of necessary competencies and the resulting problems are one of the main reasons stated as an explanation by teachers who have already left the profession (Hong, 2010).

Teacher competence is a topic that has been increasingly discussed in the last decades. One of the main reasons for this is the positive impact of teacher competence on student performance (Cunningham, 2019; Hollins, 2011). The competencies expected from qualified teachers in Estonia are: 1) subject or professional and didactic competence; 2) ability to create a safe learning environment and develop curriculum, to contribute to mutually supportive relationships between students and teachers; 3 ) ability to find links between subjects and realize opportunities for integration between subjects, to cooperate with other teachers; 4) ability to guide learning processes, including in a heterogeneous group, and to counsel learners and their relatives; 5) knowledge of problems in a multicultural learning environment and ways of solving them; 6) ability to use learning and assessment methods appropriate for learners with different preparation, level and needs; 7) ability to detect and adequately respond to developmental 


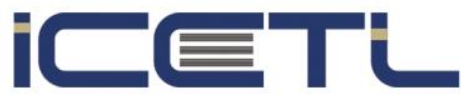

21-23 FEBRUARY, 2020

\section{$3^{\text {rd }}$ International Conference on Research in EDUCATION, TEACHING and LEARNING}

ROME, ITALY

abnormalities, social anomalies and abuse; 8) ability to create an ergonomic learning environment appropriate for human abilities and functions; 9) communication and selfexpression skills, knowledge of Estonian and foreign languages and ability to use digital technology; 10) readiness to guide learners to participate in the development of viewpoints and to represent themselves, the institution and the student body; 11) readiness for teamwork and further professional development (Õpetajate koolituse raamnõuded, 2011, §18).

Whereas in the past the assessment of a teacher's competence was primarily based on their subject matter knowledge, then today the focus is on various skills (Aud et al., 2013). Modern learning approaches increasingly emphasize the ability to adapt to change. It involves subject matter developments, teaching in a changing society, taking into account educational innovations, using technological opportunities, and coping with different values (Hollins, 2011). However, when assessing their knowledge and skills, teachers themselves have identified a number of the abovementioned competences as deficient, such as classroom management skills, methodological diversification of teaching, subject knowledge, the use of different assessment methods and the teaching of children with special needs (Aud et al., 2013). They attribute these deficiencies to inadequate teacher training (Fantilli \& McDougall, 2009).

Teachers' low ratings of their pedagogical skills and preparedness, increased societal and educational policy demands on teacher competence, and the turnover rate of novice teachers have brought into focus the quality of teacher training. Teacher training should provide teachers with thorough preparation for the competencies they need for working efficiently. However, the poor pedagogical preparation of teacher training has been criticized (Hollins, 2011) both in the international context and in Estonia (Leijen, Krull, \& Karm, 2013). The following is a more detailed overview of the causes of dissatisfaction with teacher training.

Historically, teacher training has consisted of basic and didactic subjects, and there have been no fundamental changes in these principles over time: the aim of basic training is to provide the professional knowledge that is needed for teaching, knowledge of teaching methods is acquired through didactic subjects. However, in reality, there is a big gap between students' theoretical knowledge and practical skills, as the learned skills are not practised sufficiently during the studies to acquire necessary preparation. So novice teachers start working without gaining enough competencies for teaching (Grossman, Hammerness, \& McDonald, 2009). Similar tendencies have emerged in Estonia where dissatisfaction with teacher training is caused by the pedagogical practice which does not give a sufficiently detailed impression of the teaching profession (Salu, 2018).

As teachers who are satisfied with the received education are more likely to remain in the profession, it is important to identify specific shortcomings and, consequently, to develop teacher training for graduates in order to improve their competence (DeAngelis, Wall, \& Che, 2013). The following section introduces suggestions that have been made in the past for the improvement of teacher training.

Previously, it has been proposed to firstly improve the efficiency of recruitment and selection of teacher candidates. It has also been suggested to strengthen cooperation 
between teacher training and schools so that teaching internship would help bridge the gap between practical experience and theoretical knowledge gained in teacher training (Euroopa Eripedagoogika Arendamise..., 2011). The increased amount of practice was also recommended by alumni who had left the profession. In addition, they have suggested the development of personality traits and teaching competencies and a more realistic overview of the work of teachers (Salu, 2018). In the past, it has been found that developing more realistic expectations of the teaching profession is important because the idealized perception of the teaching profession particularly influences novice teachers in coping with problems. The idealized perception of teaching profession diminishes with sufficient practice (Hong, 2010), so this may prove to be one of the main reasons of teacher turnout in case of negative experience (Salu, 2018).

Specific topics that need more attention in teacher training include: supporting of students with special educational needs, including differentiated instruction, identification of students' special needs, inclusion and the application of multicultural pedagogy in the classroom; diagnostics and assessment that supports learning, diversification of the forms and methods of learning and greater involvement of students in the planning and conducting of classes; counselling skills, including advice to parents to support the learning process; increasing the role of educational research in moving towards research and evidence-based teacher training; and advising students on career choices and developing teacher motivation and attitudes (Malva, Linde, PoomValicks, \& Leijen, 2018).

Regular development activities based on the needs of the learners are important to improve the quality of teacher training. As a result, it is important to measure student satisfaction with their teacher training (Feuer et al., 2013). Based on the abovementioned information, the aim of this research was to to identify satisfaction with teacher preparation among teacher training graduates and make recommendations for improving teacher education. To accomplish this goal, three research questions were formulated:

1. What aspects of their preparation are teaching alumni content with?

2. What are the deficiencies of the preparation of the teacher training programme in the alumni's opinion?

3. What suggestions do the alumni have for improving teacher training?

\section{Methodology}

\subsection{Sample}

The subjects of this qualitative research were found by combining convenience sampling with snowball sampling. The subjects that were included in the study had to meet the following criteria: 1) acquired a teaching qualifiation between 2016 and 2019; 2) up to three years of work experience as a teacher; and 3) lasting employment with at least 0.5 position. A total of 14 novice teachers who met all of the abovementioned criteria from one of the universities that offer teacher training in Estonia participated in the study. 


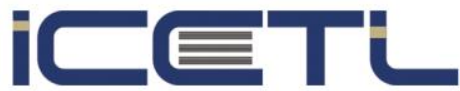

21-23 FEBRUARY, 2020 $3^{\text {rd }}$ International Conference on Research in EDUCATION, TEACHING and LEARNING

ROME, ITALY

\subsection{Data collection}

Data were collected through semi-structured interviews. The interview design was based on the theoretical part of the thesis and was divided into four blocks: 1) background information; 2) introduction; 3) satisfaction with teacher training; and 4) suggestions for improving teacher training. Previously, a pilot interview had been conducted, which was included in the data to be analyzed, as it succeeded in obtaining answers to the research questions and additions to the interview plan were kept to a minimum. The duration of the shortest interview was 41 minutes, the longest 1 hour and 43 minutes. The interviews were recorded on a smartphone with Voice Recorder and were fully transcribed.

\subsection{Data analysis}

The collected data was analyzed using a qualitative inductive content analysis method. Content analysis of the data was performed in QCAmap. Encoding was used in two interviews to increase the quality of the data analysis of the research. Meaningful units mentioned by the co-encoder and the subsequently formulated codes mostly matched the author's results.

\section{Results}

The results are presented below by research questions, highlighting the main categories formed through data analysis.

\subsection{Satisfaction with preparation}

The aim of the first research question was to find out what aspects of their preparation are teaching alumni content with. As a result of data analysis, three main categories were formed: 1) satisfaction with teaching arrangements; 2) satisfaction with courses; and 3) satisfaction with pedagogical practice.

\subsubsection{Satisfaction with teaching arrangements}

The students were satisfied with the opportunity to attend university classes twice a month in weekends to acquire their Master's degree, which was considered a flexible solution especially for those who were working or had a family. The subjects were also satisfied with a curriculum of appropriate level difficulty, which included many social subjects, with importance placed on teamwork, group discussions, and presentations. According to the subjects, they facilitated the development of presentation competence and did not require a lot of effort. They also liked the opportunity to choose more electives if they wanted to. Many interviewees expressed satisfaction with their dedicated educational specialists who provided counseling, understanding and support 


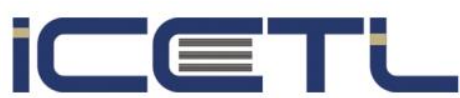

21-23 FEBRUARY, 2020

\section{$3^{\text {rd }}$ International Conference on Research in EDUCATION, TEACHING and LEARNING}

ROME, ITALY

during their studies that facilitated learning. Satisfaction with study allowances and scholarships was also mentioned, which eased the economic pressure to work while studying and allowed them to focus on acquiring education.

\subsubsection{Satisfaction with subjects}

The interviewees were satisfied with the general theoretical basis obtained from different subjects. Satisfaction was highest with the subjects related to the planning and conducting of classes. More specifically, the interviewees were most content with the majority of didactic subjects and those where active learning methods were used. The alumni explained that the subjects that required practice provided them with a better preparation for the reality of teaching.

Satisfaction with subjects was closely related to the lecturers and the work of the lecturers who diversified their studies was particularly highlighted. For example, alumni enjoyed role plays, mini lessons, communication exercises, field trips and studying outdoors. According to the interviewees, teacher training addressed in sufficient detail a number of topics needed for teaching work which were practiced sufficiently to provide necessary practice. Satisfaction was high in the following: skills to search for information, plan a lesson, create a lesson plan and conduct lesson observation; ability to design subjectware, reflect on activities and target them.

\subsubsection{Satisfaction with pedagogical practice}

According to the interviewees, pedagogical practice resembled what they had already learned in theory and helped integrate the studies into a whole. The alumni also liked the length of the internship and its flexibility, for example, teachers could complete their internship (period during which the student has a traineeship at school) in their workplace with their students or the fact that observational internships could be conducted in pairs, which helped in later analysis.

Several novice teachers said that their supervisors played an important role in their internship and commented that their practical experience was especially useful and pleasant due to their competent and supporting mentor. According to many teachers, their supervisor recommended to practice the conducting of lessons as soon as possible which make their practical experience very useful and increased their motivation.

\subsection{Deficiencies in preparation}

The aim of the second research question was to find out what are the deficiencies of the preparation of the teacher training programme in the alumni's opinion. As a result of data analysis, three main categories emerged: 1) deficiencies in teaching arrangements; 2) deficiencies in courses; and 3) deficiencies in pedagogical practice. 


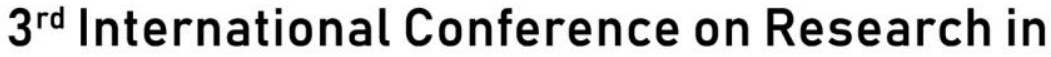 EDUCATION, TEACHING and LEARNING}

ROME, ITALY

\subsubsection{Deficiencies in teaching arrangements}

The subjects thought that there were many unnecessary $s$ in their curriculum. They mentioned that those subjects focused on irrelevant topics and did not provide them with any new knowledge or skills that would be useful for working as a teacher. It was also pointed out that the curriculum of non-stationary studies contained subjects that had to be completed in the form of stationary study. In addition, some sessions took place more frequently than was stated at first, for example, twice a month instead of once. Some of the interviewees also expressed dissatisfaction with choosing elective subjects to the extent prescribed in the curriculum, which they did not have the opportunity to complete throughout their studies because the subjects were not read / open during their studies.

The interviewees also considered the location, especially the choice of classrooms, as one of the shortcomings in the teaching arrangements. Dissatisfaction with uncomfortable tables and chairs was also expressed, and some rooms were considered unsuitable for studying due to poor acoustics, poor ventilation and insufficient lighting, which made it difficult to focus on the tasks at hand.

\subsubsection{Deficiencies in courses}

When it comes to university subjects, dissatisfaction was expressed with unqualified lecturers, who in the alumni's opinion, placed too much importance on the form of lecture and theoretical knowledge, which made some subjects abstract, voluminous, complicated or boring. The repetition of similar subjects, tasks and activities was also considered a shortcoming.

Dissatisfaction was also caused by insufficient or inadequate treatment of a number of issues. These topics included, for example, supporting students with special educational needs; assessment and formulation of learning outcomes; use of digital tools and solutions in teaching; classroom management and performance reviews; correspondence and communication in difficult situations, self-control and conflict resolution; preparation of study materials; application of professional methodologies, active learning, general education and other current trends, and topics related to legislation and documentation. According to the respondents, these topics were mostly solely mentioned in theory and not practised. Even if mini lessons and role play was used as a teaching method, it was often ineffective and seemed artificial.

The interviewees also considered the lack of familiarity with many of the teachers' daily tasks, their challenges, and the large amount of time involved in their work as a shortcoming of the teacher training programme. The alumni said that at the university, the creating and conducting of modern lessons based on active learning was claimed to be the most valued task of teachers. The additional responsibilities were barely talked about, idealized or just success stories that did not deal with the most frequent problems of teachers, work overload and burnout of novice teachers, and skills to deal with tension and stress. 


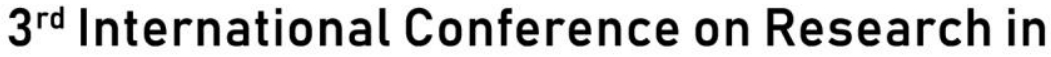 EDUCATION, TEACHING and LEARNING}

ROME, ITALY

\subsubsection{Deficiencies in pedagogical practice}

The shortcoming of several practical subjects was considered to be their volume, the place, the time, the assignments or a mentor who did not meet expectations. The internship was often said to be too short to give a realistic picture of teaching work. For some students, however, the internship had been an unnecessary additional obligation because they already had previous experiences as a teacher. The students' needs were often not taken into consideration when choosing the place and time for the internship, and the students felt that the internship started too late in their studies. Many interviewees said that their entos were unqualified due to lack of interest and low instructing skills. In rather many cases, the supervisor did not give the student an adequate overview of teachers' work.

\subsection{Recommendations for improving teacher training}

The aim of the third research question was to find out what recommendations do the alumni make for improving teacher training. As a result of data analysis, three main categories emerged: 1) recommendations for improving teaching arrangements; 2) recommendations for improving courses; and 3) recommendations for improving pedagogical practice.

\subsubsection{Recommendations for improving teaching arrangements}

Several teachers suggested that admissions to teacher training could be gained through stricter selection to reduce the number of drop-outs and students who do not intend to become teachers. It was said that the initial prerequisites for working as a teacher, such as communication and presentation skills, should already be acquired before the start of higher education and the existence of these abilities should be checked as soon as the candidates apply for teacher training. It was suggested that the candidates should be interviewed and they should solve an educational problem, as well as pass a professional skills test based on the subjects they are planning to teach and present themselves in front of an audience.

It was also pointed out that instead of groups of students from different curriculums, it would be more beneficial in seminars and workshops to study together with students who have the same curriculum. In the alumni's opinion, this change would make university education more individualized. It was also proposed to increase teacher training programme's cooperation with educational institutions and teachers. It was explained that this would be needed to involve practicing teachers in introducing teaching work to students in teacher training. The alumni believed it would be important to collaborate with schools so that students could practice teaching in a real environment.

In relation with the aforementioned information, the interviewees felt that teaching, practicing and working as a teacher could be more connected, for example, the acquisition of theoretical knowledge in different subjects could alternate with practicing 


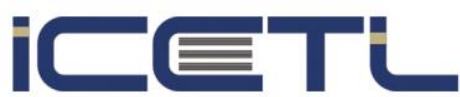

21-23 FEBRUARY, 2020

\section{$3^{\text {rd }}$ International Conference on Research in EDUCATION, TEACHING and LEARNING}

ROME, ITALY

the learned skills in a real school environment. Some alumni suggested that students with prior or parallel teaching experience should apply their experiences in their academic work. Another suggestion for teacher training was the idea that after completing a Master's degree, novice teachers should be appointed a mentor by the university in their first year of work.

\subsubsection{Recommendations for improving courses}

Novice teachers who participated in the study expressed their opinion that a number of older subjects in the curriculum needed general updates and refreshments. It was thought that lecturers could incorporate new materials, more practical assignments, more active learning methods, invite practitioners to speak, and create opportunities for discussion and deeper thinking.

It was also suggested that, to some extent, the lecturers themselves could regularly teach lessons in a school. Subjects that were considered too voluminous, difficult, or boring were recommended to be taught in smaller parts or at a later stage of the studies and alternating with practice.

When it comes to specific topics that were considered insufficiently addressed in teacher training, it was recommended that more attention be paid to: formulation of learning outcomes, formative assessment and feedback on student work; legislation and knowledge of teachers' rights. It was felt that the topic of coping with children with special educational needs, the use of digital tools and different educational resources, the application of active learning methods and the diversification of teaching also needed further consideration and practice. It was also recommended to focus more on documentation related issues: preparation of work plans, development maps, etc., and documentation; in addition, focus more communication related topics, written and verbal problematic conversations, development discussion, and communication with colleagues and management. It was recommended to increase the volume of practical tasks at the expense of theoretical ones, replace lectures with e-learning, reduce repetition and provide alternative assignments based on the needs of students.

Novice teachers suggested that teacher training should give a realistic overview of teachers' work. To achieve this goal, the various tasks of teachers, such as classroom management, assessment, feedback, event organization, project participation, documentation, field trips, and meetings should be explained. According to the alumni, teacher training should prepare students for the often heavy workload and additional responsibilities of teachers, the complexity of the job, and the fact that the work can be both physically exhausting and emotionally difficult at the start. Many of the interviewees admitted that problems they had not anticipated had led them to consider leaving the teaching profession, so they recommended that, alongside success stories, both teaching and practicing as well as retired teachers should talk about their negative experiences also.

Because many interviewees were unaware of all kinds of support systems, both in and outside their workplace, at the start of their work, it was suggested that lecturers should talk about support systems for novice teachers, such as introducing them in 


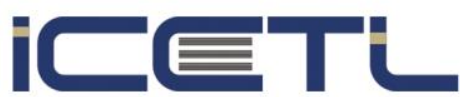

21-23 FEBRUARY, 2020

\section{$3^{\text {rd }}$ International Conference on Research in EDUCATION, TEACHING and LEARNING}

ROME, ITALY

theory and inviting program representatives and participants to talk about them in more detail.

\subsubsection{Recommendations for improving pedagogical practice}

According to the interviewees, the development of a more realistic image of the teaching profession and the skills needed for it would be facilitated by more efficient internship organization. One suggestion was to increase the volume of internship so that students could spend more valuable time in the work environment. However, those who had already worked as a teacher before the internship thought that students with previous teaching experience could be exempted from the internship.

The selection of supervisors was also a topic that the research participants recommended to improve. It was suggested that only those people should become mentors who are happy to accept this obligation and they should certainly receive appropriate training and incentive payments, and have less responsibilities at work while they are active mentors, so that they could spend more time on teaching their practitioner. It was said that the university should inform the mentors about their roles and tasks since, according to many interviewees, the mentors did not know them.

\section{Discussion}

The aim of this research was to identify satisfaction with teacher preparation among teacher training graduates and make recommendations for improving teacher training. The most important results of the research are discussed below.

It is important to point out that the results clearly distinguished the importance of the organizational aspects of learning, such as the form of study, the curriculum or the physical conditions in which classes were conducted. From a theoretical point of view, there was little indication to the degree to which alumni satisfaction was influenced by the organizational aspects of teacher training. As a result, the shortcomings highlighted by this research should certainly be reduced, for example, it should be ensured that nonstationary studies are conducted only during sessions and that the amount of lectures does not exceed the time frame in the curriculum; the amount of seminars and practical work should also be increased and teaching work should only take place in effective classrooms with the necessary physical equipment.

The results of the study show that alumni who had previous teaching experience or worked as teachers while studying were pleased with this arrangement, because they received support while learning teaching, as it provided them with personal experiences that helped them better understand the knowledge they acquired during teacher training. Thus, the results of this study suggest that earlier or parallel teaching practice supports teacher training. The proposal of the subjects to integrate more practical training opportunities into basic studies, such as lesson observation, teaching of fellow students or conducting classes in an educational institution, could have a positive effect on the preparation of novice teachers.

Many of the novice teachers who mentioned a lack of understanding of the teaching profession pointed out that their mentors and colleagues supported them a lot and 
helped them overcome thoughts about quitting their teaching job. It can be concluded that effective support systems for novice teachers make up for the inadequacies of teacher training and effectively help cope with the tasks and problems of teachers. On the other hand, it can also be concluded that novice teachers, who face a variety of unexpected responsibilities and difficulties at a new job, and are not sufficiently supported, will soon leave the profession. Previous studies have had similar results (DeAngelis et al., 2013). Therefore, it is certainly important to pay attention to improving the competence of mentor teachers. Educational institutions should also consider giving the responsibilities of a mentor only to those people who are willing to accept it. Because of the importance of the topic, the author believes it is important to consistently conduct research in order to ensure more effective work adaptation and retention of novice teachers.

\section{References}

[1] Aud, S., Wilkinson-Flicker, S., Kristapovich, P., Rathbun, A., Wang, X., \& Zhang, J. (2013). The Condition of Education 2013. Washington DC: National Center for Education Statistics, US Department of Education.

[2] Cunningham, B. (2019). Examining the Relationship Between Teacher Preparation Program Quality and Beginning Teacher Retention. Georgia State University. Available: https://scholarworks.gsu.edu/cgi/viewcontent.cgi?article=1224\&context=eps_diss

[3] DeAngelis, K. J., Wall, A. F., \& Che, J. (2013). The impact of preservice preparation and early career support on novice teachers' career intentions and decisions. Journal of teacher education, 64(4), pp. 338-355.

[4] Euroopa Eripedagoogika Arendamise Agentuur. (2011). Projekt "Kaasamist toetav opetajakoolitus”. Poliitikasoovitused. Available: https://www.europeanagency.org/sites/default/files/teacher-education-for-inclusion-key-policymessages_TE4i-policypaper-ET.pdf

[5] Fantilli, R. D., \& McDougall, D. E. (2009). A study of novice teachers: Challenges and supports in the first years. Teaching and teacher education, 25(6), pp. 814-825.

[6] Farrell, T. S. (2012). Novice service language teacher development: Bridging the gap between preservice and in-service education and development. Tesol Quarterly, 46(3), pp. 435-449.

[7] Feuer, M. J., Floden, R. E., Chudowsky, N., \& Ahn, J. (2013). Evaluation of Teacher Preparation Programs: Purposes, Methods, and Policy Options. Washington DC: National Academy of Education.

[8] Grossman, P., Hammerness, K., \& McDonald, M. (2009). Redefining teaching, reimagining teacher education. Teachers and Teaching: Theory and Practice, 15(2), pp273-289.

[9] Haridus- ja Teadusministeerium. (2018). Haridus- ja Teadusministeeriumi 2018. aasta tulemusaruanne. Tartu: HTM.

[10] Hollins, E. R. (2011). Teacher preparation for quality teaching. Journal of Teacher education, 62(4), pp. 395-407. 


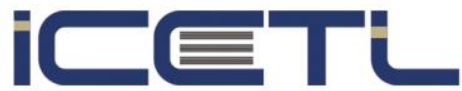

21-23 FEBRUARY, 2020 $3^{\text {rd }}$ International Conference on Research in EDUCATION, TEACHING and LEARNING

ROME, ITALY

[11] Hong, J. Y. (2010). Pre-service and beginning teachers' professional identity and its relation to dropping out of the profession. Teaching and teacher Education, 26(8), pp. $1530-1543$.

[12] Ingersoll, R., Merrill, L., \& Stuckey, D. (2014). Seven trends: The transformation of the teaching force.

Available:

http://www.cpre.org/sites/default/files/workingpapers/1506_7trendsapril2014.pdf

[13] Leijen, Ä., Krull, E., \& Karm, M. (2013). Eessõna. Eesti Haridusteaduste Ajakiri. Estonian Journal of Education, 1, pp. 1-7.

[14] Malva, L., Linde, M., Poom-Valickis, K., \& Leijen, Ä. (2018). OECD ÕPETAJA PEDAGOOGILISTE TEADMISTE PILOOTUURINGU EESTI RAPORT. Available: https://www.hm.ee/sites/default/files/uuringud/oecd_opetaja_pedagoogiliste_teadmiste_ pilootuuringu_eesti_raport_002.pdf

[15] Salu, E. (2018). Õpetajate arvamused õpetajate töölt lahkumise kohta. Magistritöö. Tartu Ülikool.

[16] Selliov, R., \& Vaher, K. (2018). Õpetajakoolituse lõpetanud ja alustavad õpetajad EHISe andmetel. Tartu: Haridus- ja Teadusministeerium.

[17] Valk, A. (2016). Opetajaameti atraktiivsus. Tartu: Haridus- ja Teadusministeerium.

[18] Õpetajate koolituse raamnõuded (2011). Riigi Teataja I 2011, 3, 22. Available: https://www.riigiteataja.ee/akt/122032011015 